Note

\title{
Transient initial phase in continuous culture of Isochrysis galbana affinis Tahiti
}

\author{
Gaël Bougaran *, Loïc Le Déan, Ewa Lukomska, Raymond Kaas, Régis Baron \\ IFREMER, rue de l'Ile d'Yeu, 44311 Nantes cedex 3, France \\ Received 17 February 2003; accepted 25 April 2003
}

\begin{abstract}
Starting microalgae continuous culture generally includes a preliminary batch culture to obtain sufficient cell density. It is possible to apply continuous regime from the beginning of the culture (IC mode) rather than to begin by an initial batch (IB mode). It is our purpose to check that both initial modes lead to identical steady-state cell characteristics. The microalga Isochrysis galbana affinis Tahiti was used for this comparative study. With an initial cell density of $5 \times 10^{5} \mathrm{cell} \mathrm{ml}^{-1}$ and a dilution rate of about $1.0 \mathrm{~d}^{-1}$, both IB and IC modes led to identical cell density once steady-state is reached between 6 and $8 \mathrm{~d}$ after inoculation in the two cases. Cell concentration of chlorophyll $a$ and pheopigment $a$ were found to be similar for IB and IC modes at steady-state. Initial culture conditions did not influence saturation irradiance and oxygen consumption rate, which were found to be $650 \pm 143 \mu \mathrm{mol}$ phot $\mathrm{m}^{-2} \mathrm{~s}^{-1}$ and $1.54 \times 10^{-3} \pm 10^{-5} \mu \mathrm{mol} \mathrm{O}_{2} \mathrm{ml}^{-1} \mathrm{~min}^{-1}$, respectively. At steady-state, nutrient cell uptakes were $\rho_{\mathrm{N}}=83.3 \pm 2.0 \mathrm{fmol} \mathrm{N}$ cell ${ }^{-1} \mathrm{~d}^{-1}$ for $\mathrm{NO}_{3}{ }^{-}$and $\rho_{\mathrm{P}}=5.5 \pm 0.4 \mathrm{fmol} \mathrm{P}$ cell ${ }^{-1} \mathrm{~d}^{-1}$ for $\mathrm{H}_{2} \mathrm{PO}_{4}^{-}$and did not exhibit significant differences between IB and IC modes. Under the prevailing experimental conditions, results show that IC mode involved very similar steady-state cell characteristics when compared to IB mode subsequent steady-state. IC mode could be an attractive alternative especially for experimental laboratory studies, as it should lead to higher flexibility in starting continuous cultures.
\end{abstract}

(C) 2003 Éditions scientifiques et médicales Elsevier SAS and Ifremer/IRD/Inra/Cemagref. All rights reserved.

Keywords: Continuous culture; Steady-state; Photosynthesis; Cell quota; Isochrysis

\section{Introduction}

Live microalgae are essential feed for larvae and juveniles of bivalve molluscs. Alternatives tested (dried, heterotrophically grown microalgae, compounded microcapsules, lipid emulsion or yeasts and bacteria) have had lower nutritional value than mixtures of microalgae commonly used in aquaculture (Robert and Trintignac, 1997). In many hatcheries molluscs are fed with different species such as Chaetoceros calcitrans, Pavlova lutheri, Thalassiosira pseudonana (Brown et al., 1998; McCausland et al., 1999) and the prymnesiophyceae Isochrysis galbana affinis Tahiti (T-iso). These cells are commonly grown using batch cultures. Biomass grown in these conditions has a varying composition and remains expensive to produce: live food production contributes up to $30 \%$ of the total cost of production (ValenzuelaEspinoza et al., 1999) and is considered the major bottleneck in nursery culturing of molluscs (Fabregas et al., 1986).

* Corresponding author.

E-mail address: gael.bougaran@ifremer.fr (G. Bougaran).
During batch production, environmental factors alteration induce modification in cells: biochemical composition of cells depends on many factors such as irradiance (Rebolloso Fuentes et al., 2000), specific growth rate (Fernandez et al., 1998; Otero and Fabregas, 1997), medium composition (Fabregas et al., 1985), pH and harvest stage (Brown et al., 1993). The biochemical composition of T-iso shows higher protein content during exponential phase and higher glucide and lipid content during stationary phase (Brown et al., 1993; Zhu, 1997; Fidalgo et al., 1998; Phatarpekar et al., 2000).

Borowitzka (1999) argues in favour of continuous culture and good control over the growth environment, which result in a consistent product quality. Examples of continuous culture can easily be found in literature, but authors rarely describe the culture mode (i.e. batch or continuous) they use during the transitional phase prior to steady-state. When they do, initial batch culture (IB mode) is commonly used to obtain sufficient cell density (Alonso et al., 2000; D'Souza and Kelly, 2000). The use of continuous culture immediately after inoculation (IC mode) could be an interesting alternative, which would provide the possibility of global process 
automation without requiring the use of a turbidimeter. The aim of this study is to confirm standard chemostat theory under the prevailing experimental conditions, showing that IC mode does not induce any difference on steady-state when compared with IB mode culture. In two successive sets of experiments, IC and IB mode cultures were carried out at the same time until steady-state was reached. Various parameters such as cell density, biomass, nutrient ( $\mathrm{N}$ and $\mathrm{P}$ ) uptake and photosynthesis characteristics were checked in order to compare cell populations grown with the two initial culture modes.

\section{Materials and methods}

\subsection{Experimental device}

The experimental device (Fig. 1) includes six 2.2-1 stirred-tank polymethyl methacrylate bioreactors ( $\varnothing=126 \mathrm{~mm}, H=214 \mathrm{~mm}$ ). Cultures were stirred by a 4-paddle impeller turbine at a rate of $120 \mathrm{rpm}$. The upper head plate of the bioreactor was designed to support all probes and tubing. The probes were connected to a computer data-acquisition system equipped with a microprocessor interface board with 32 analog channels. Each bioreactor used four channels to collect data on light absorption, temperature, $\mathrm{pH}$ and gas flow. A probe based on the Beer-Lambert law was designed to measure light absorption of microalgal cells and provide on-line estimation of biomass after standardization with cell density. An on-line $\mathrm{pH}-$ meter transmitted measurements to a central computer that controlled $\mathrm{pH}$ value by injecting $\mathrm{CO}_{2}$ into the bioreactors. The entire system was controlled by a computer equipped with specific software developed in Visual Basic, which managed probe calibration and on-line recording of culture parameters. The reactors were placed in a heat-regulated culture facility, with continuous light. Light was delivered by two 36-W fluorescent tubes (Philips TLD) to each bioreactor. The system was adapted to continuous-flow culture by adding a KNF STEPDOS diaphragm pump to supply nutrients and an ISMATEC peristaltic pump to collect overflow fractions.

\subsection{Cultivation conditions}

Growth medium was prepared with natural coastal seawater (origin St. Malo, France), enriched with $1 \mathrm{ml} \mathrm{l}^{-1}$ of Walne solution (1966). Seawater was filtered with a $0.45 / 0.22 \mu \mathrm{m}$ SARTORIUS filter. Each bioreactor was supplied with its own storage tank in which culture medium solutions were directly assembled.

Supply and harvest pipes and photobioreactors were sterilized with a solution of $0.5 \%$ peroxyacetic acid for $20 \mathrm{~min}$ and then rinsed three times with deionized water. Cultures were grown at $27 \pm 0.5^{\circ} \mathrm{C}$ in continuous light. Irradiance was $110 \pm 10 \mu \mathrm{mol}$ phot $\mathrm{m}^{-2} \mathrm{~s}^{-1}$ in the middle of empty bioreactors as measured with a spherical Li-Cor LI193 quantum scalar meter. $\mathrm{pH}$ was regulated at $7.20 \pm 0.05$ and gas were filtered through a $0.22 \mu \mathrm{m}$ Teflon membrane at a rate of $0.20 \pm 0.051 \mathrm{~min}^{-1}$. Impeller speed was set to $120 \mathrm{rpm}$. Dilution rates were $1.00 \mathrm{~d}^{-1}$ in the first experiment and $1.08 \mathrm{~d}^{-1}$ in the second experiment.

Inoculum was produced in a continuous flow culture with a $1 \mathrm{~d}^{-1}$ dilution rate at steady-state. All bioreactors were

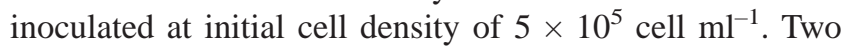

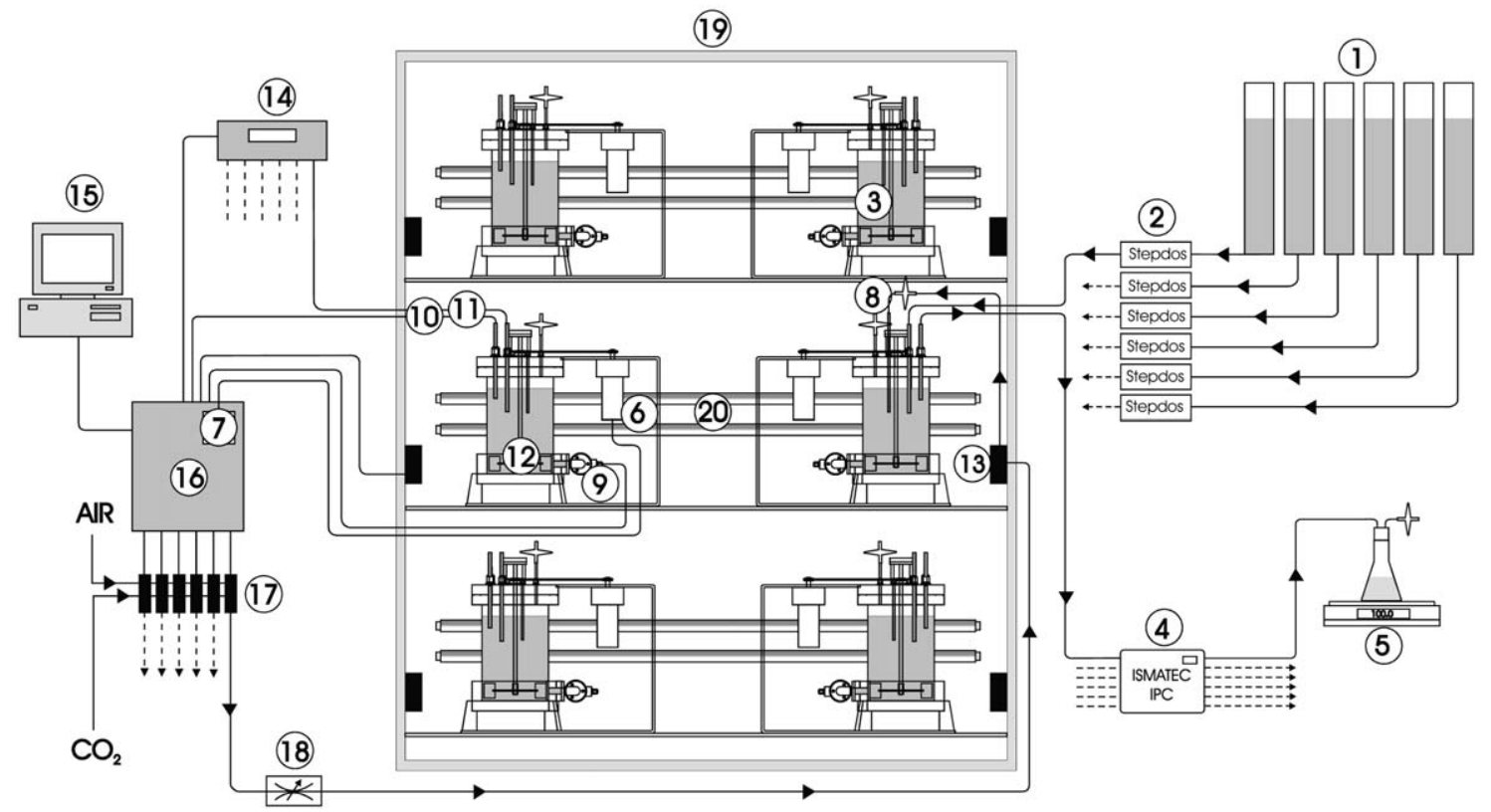

Fig. 1. Experimental installation: 1, culture medium tank; 2, stepdos pump; 3, photobioreactor; 4, peristaltic pump; 5, harvest scale; 6, impeller motor; 7, motor speed controller; 8, $0.22 \mu \mathrm{m}$ gas filter; 9, absorption probe; 10, temperature probe; 11, $\mathrm{pH}$ combined electrode; 12, four-paddle impeller turbine; 13, airflow sensor; 14, pH-meter; 15, supervising computer; 16, data acquisition and digital output board; 17, electrovalve; 18, air flow regulator; 19, illuminated incubator; 20, fluorescent tubes. 
experiments were successively carried out. Two initial batch mode cultures and two initial continuous mode cultures were grown in the first experiment while three of each were grown in the second. Initial batch mode (IB) first uses a batch phase to attain higher cell density before starting continuous flow. On the contrary, initial continuous mode (IC) cultures are immediately grown in continuous flow since they are inoculated.

Prior to biomass analysis, steady-state was assessed on a cell-density basis and maintained for at least $4 \mathrm{~d}$ to assure constant biomass composition (Molina Grima et al., 1996).

\subsection{Analytical methods}

Cell population kinetic in bioreactors was monitored with on-line light absorption probes, with absorbance at $800 \mathrm{~nm}$ $\left(A_{800}\right)$ and cell counts. On-line light absorption probe provides a continuous and real time estimation of biomass but is subjected to deviations due to fouling of optical surfaces in long duration culture. Nevertheless, this information is very helpful for the daily process control. Near infrared absorbance is often used for biomass control (Versteegh et al., 2001; Schmitt et al., 2001; Sciandra et al., 2000). Therefore, $A_{800} /$ cell ratio can be used as an indicator of cellular biomass. $A_{800}$ absorbance was measured using a MILTON ROY Genesys 5 spectrophotometer. Cell density was measured daily in the outflow of cultures by microscopic counting using a Malassez slide and Lugol fixing solution. Cells were automatically counted with an image analysis software; the application used was developed in the laboratory using the SAMBA environment (Samba Technologies, Meylan, France). The variation coefficient of this method was estimated to be less than $6 \%$. Dry weight were determined at the end of the first experiment by filtering $25 \mathrm{ml}$ of the culture sample onto tarred GF/C Whatman filters earlier dried at $70{ }^{\circ} \mathrm{C}$. The filtered sample was then washed three times with $25 \mathrm{ml}$ of a $34 \mathrm{~g} \mathrm{l}^{-1}$ ammonium formate solution and then dried at $70{ }^{\circ} \mathrm{C}$ for $24 \mathrm{~h}$ before weighing. Three dry weights were performed for each culture for confidence interval determination.

Major anions concentration ( $\mathrm{N}$ and $\mathrm{P}$ ) was measured daily in all cultures and when new medium solutions were prepared in culture medium tanks. Nutrient uptake $(\rho)$ was calculated at steady-state using the following equation

$$
\rho_{\mathrm{s}}=\frac{D\left(S_{\mathrm{i}}-S\right)}{X}
$$

where $\rho_{\mathrm{s}}$ is nutrient uptake per cell (fmol cell $\left.{ }^{-1} \mathrm{~d}^{-1}\right), X$ is cell density $\left(\right.$ cell $\left.\mathrm{l}^{-1}\right), D$ is dilution rate $\left(\mathrm{d}^{-1}\right), S_{\mathrm{i}}$ is inflow nutrient concentration ( $\mathrm{fmol}^{-1}$ ) and $S$ is residual nutrient concentration in the bioreactor (fmol $\left.1^{-1}\right)$. Cell quotas $\left(Q_{\mathrm{N}}\right.$ and $\left.Q_{\mathrm{P}}\right)$ were calculated using Eq. (2) when steady-state was reached.

$$
\frac{\mathrm{d} Q_{\mathrm{s}}}{\mathrm{d} t}=\rho_{\mathrm{s}}-\mu Q_{\mathrm{s}}
$$

where $\mu$ is the specific growth rate $\left(\mathrm{d}^{-1}\right)$. Analyses were performed by ionic chromatography using a DX500 (DI-
ONEX) fitted with an AS9-HC column. One millilitre samples were $0.22 \mu \mathrm{m}$ filtered and then diluted with $14 \mathrm{ml}$ of 18.2 $\mathrm{M} \Omega$ deionized water to reduce chloride concentration. The threshold for $\mathrm{NO}_{3}{ }^{-}$and $\mathrm{HPO}_{4}{ }^{2-}$ detection was 15 and $4 \mu \mathrm{mol} \mathrm{l}{ }^{-1}$, respectively. $\mathrm{NO}_{3}{ }^{-}$and $\mathrm{HPO}_{4}{ }^{2-}$ represent all the $\mathrm{N}$ and $\mathrm{P}$ species in the medium solution used. All the biomass and ionic concentrations given in this paper are the means of data collected during the steady-state period.

Chlorophyll $a(\mathrm{Chl} a$ ) and pheopigments $a$ (Pheo $a$ ) were determined at the end of the experiments using Lorenzen method (1967). After extraction absorbance was measured at 665 and $750 \mathrm{~nm}$ using a $10 \mathrm{~mm}$ optical length path quartz cell and a MILTON ROY Genesys 5 spectrophotometer. Photosynthetic activity was measured as oxygen production using a HANSATECH Oxylab unit fitted with a Clark electrode. After an 1 min nitrogen flushing, $0.5 \mathrm{ml}$ of a $144 \mathrm{mmol} \mathrm{l}^{-1}$ $\mathrm{NaHCO}_{3}$ solution was added to $11.5 \mathrm{ml}$ of sample in the measurement chamber. A 20 min light/10 min dark cycle was then applied. Irradiance was constant during one period but increased from one period to the next.

Results are compared using 95\% ANOVA test performed with Statgraphics Plus 3.1 and expressed with the $95 \%$ confidence interval in brackets except when otherwise specified.

\section{Results}

\subsection{Cell population}

In the two experiments, the cell density reached steadystate after 6-8 d after inoculation (Fig. 2). Initial culture mode did not induce significant differences between IC and IB steady-states (ANOVA test). In the first experiment, mean cell density averaged $9.0 \times 10^{6}\left(0.3 \times 10^{6}\right) \mathrm{cell} \mathrm{ml}^{-1}$ in both IC and IB modes. Mean cell density was slightly lower in the six cultures of the second experiment and averaged $7.7 \times 10^{6}$ $\left(0.2 \times 10^{6}\right)$ cell $\mathrm{ml}^{-1}$.

Biomass was determinated $13 \mathrm{~d}$ after inoculation and showed no significant differences between IC and IB modes in the first experiment (ANOVA test). Mean biomass in the four cultures was $0.14(0.01) \mathrm{g} \mathrm{l}^{-1}$ (Table 1). In the two sets of experiment $A_{800} /$ cell ratio did not show significant differences between IC and IB modes either (ANOVA test).

ANOVA test revealed that both IC and IB modes achieved the same cumulated cell production in each experiment (Table 2).

\subsection{Photosynthetic apparatus}

Chl $a$ and Pheo $a$ were analysed at day 13 and did not show significant difference between IC and IB modes (Table 3 ). The (Pheo $a /(\mathrm{Chl} a+\mathrm{Pheo} a)$ ) ratio is, therefore, comparable in the two cases.

Oxygen production and respiration could not be measured at the end of the first experiment. The photosynthetic characteristics of the six cultures grown in the experiment 2 were determined at steady-state (day 13). Table 4 shows the results 

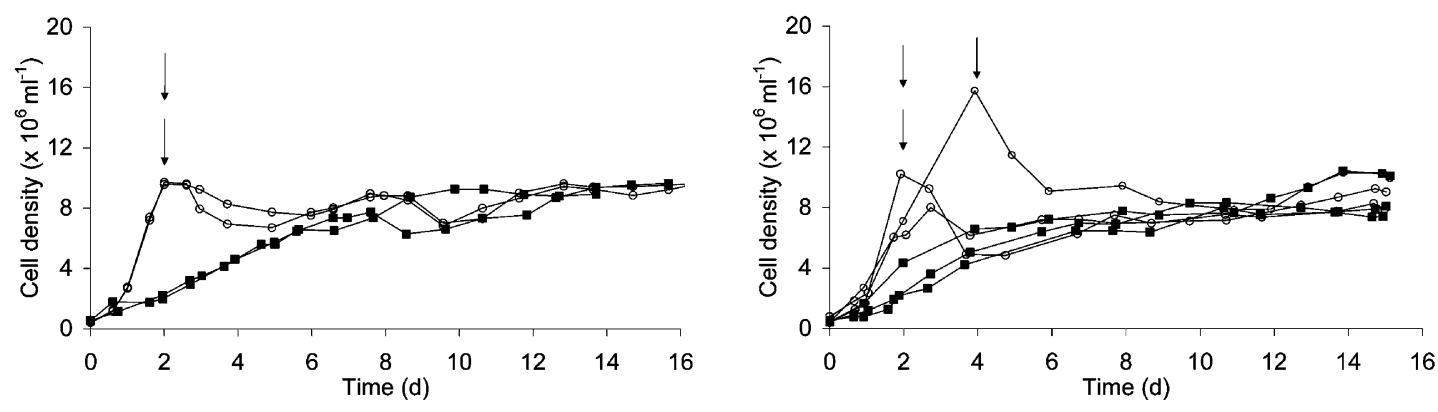

Fig. 2. Time course of cell density during the first (left) and the second (right) experiments. Solid squares: initial continuous cultures; open circles: IB mode. Arrows show the end of batch periods.

Table 1

Steady-state DW and $A_{800} /$ cell ratio comparison between IC and IB modes at day 13. Ninety-five percent confidence intervals are given in brackets. (-) DW determination could not be made

\begin{tabular}{lllll}
\hline & DW $\left(\mathrm{g}^{-1}\right)$ & & $A_{800} /$ cell $\left(10^{-6} \mathrm{ml} \mathrm{cell}^{-1}\right)$ & \\
& IB & IC & IB & IC \\
\cline { 2 - 5 } Experiment 1 $(n=2)$ & $0.13(0.02)$ & $0.15(0.02)$ & $4.12 \times 10^{-2}\left(0.07 \times 10^{-2}\right)$ & $4.12 \times 10^{-2}\left(0.08 \times 10^{-2}\right)$ \\
Experiment 2 $(n=3)$ & - & - & $3.83 \times 10^{-2}\left(0.09 \times 10^{-2}\right)$ & $3.88 \times 10^{-2}\left(0.10 \times 10^{-2}\right)$ \\
\hline
\end{tabular}

Table 2

Cumulated cell productions $\left(\times 10^{6}\right.$ cell $\left.\mathrm{ml}^{-1}\right)$ calculated at day 13 in IC and IB mode cultures. Ninety-five percent confidence intervals are given in brackets

\begin{tabular}{lll}
\hline & IB & IC \\
\hline Experiment 1 & $89.5(15.6)$ & $79.4(15.6)$ \\
Experiment 2 & $111.6(34.6)$ & $100.7(25.8)$ \\
\hline
\end{tabular}

Table 3

Chl $a$ and Pheo $a$ cells concentration at steady-state. Ninety-five percent confidence intervals are given in brackets

\begin{tabular}{lllll}
\hline & & $\begin{array}{l}\text { Chl } a \\
\left(\mathrm{pg} \mathrm{cell}{ }^{-1}\right)\end{array}$ & $\begin{array}{l}\text { Pheo } a \\
\left(\mathrm{pg} \mathrm{cell}{ }^{-1}\right)\end{array}$ & $\begin{array}{l}\text { Pheo } a \\
(\mathrm{Chl} a+ \\
\text { Pheo } a)\end{array}$ \\
\hline Experiment 1 & IB & $0.23(0.04)$ & $0.026(0.007)$ & 10 \\
& IC & $0.25(0.01)$ & $0.023(0.003)$ & 10 \\
Experiment 2 & IB & $0.22(0.02)$ & $0.012(0.002)$ & 5 \\
& IC & $0.22(0.001)$ & $0.012(0.002)$ & 5 \\
\hline
\end{tabular}

Table 4

Compensation irradiance $\left(I_{\mathrm{c}}\right)$, saturation irradiance $\left(I_{\mathrm{s}}\right)$ and maximum gross photosynthesis related to $\mathrm{Chl} a\left(P_{\mathrm{g} \mathrm{Chl} a}{ }^{\mathrm{max}}\right)$ recorded at steady-state at the end of experiment 2. Ninety-five percent confidence intervals are given in brackets

\begin{tabular}{|c|c|c|c|}
\hline & $\begin{array}{l}I_{\mathrm{c}} \\
\left(\mu \mathrm{mol} \text { phot } \mathrm{m}^{-2} \mathrm{~s}^{-1}\right)\end{array}$ & $I_{\mathrm{s}}$ & $\begin{array}{l}P_{\mathrm{g} \mathrm{Chl} a}{ }^{\max } \\
\left(\mu \mathrm{mol} \mathrm{O}_{2} \mathrm{mg} \mathrm{Chl} a^{-1} \mathrm{~min}^{-1}\right)\end{array}$ \\
\hline$\overline{\mathrm{IB}}$ & $27(8)$ & 667 (143) & $2.57(0.71)$ \\
\hline IC & $28(7)$ & $633(143)$ & $2.75(0.86)$ \\
\hline
\end{tabular}

of compensation irradiance $\left(I_{\mathrm{c}}\right)$, saturation irradiance $\left(I_{\mathrm{s}}\right)$ and maximum gross photosynthesis related to $\mathrm{Chl} a\left(P_{\mathrm{g} \mathrm{Chl} a}{ }^{\max }\right)$. No significant difference was found between the two IB and IC modes for these three criteria (ANOVA test).

In the six cultures of experiment 2 , volumic respiration $(R)$ and saturating gross photosynthesis $\left(P_{\mathrm{g}}{ }^{\max }\right)$ rates did not significantly differ between IC and IB modes at steady-state (ANOVA test). Results are shown in Table 5.
Table 5

Volumic respiration and saturating gross photosynthesis mean rates calculated at steady-state of experiment $2(n=6)$. Ninety-five percent confidence interval are given in brackets

\begin{tabular}{ll}
\hline$R\left(\mu \mathrm{mol} \mathrm{O} \mathrm{ml}^{-1} \mathrm{~min}^{-1}\right)$ & $P_{\mathrm{g}}^{\max }\left(\mu \mathrm{mol} \mathrm{O} \mathrm{ml}^{-1} \mathrm{~min}^{-1}\right)$ \\
\hline$-1.54 \times 10^{-3}\left(0.01 \times 10^{-3}\right)$ & $5.1 \times 10^{-3}\left(0.8 \times 10^{-3}\right)$ \\
\hline
\end{tabular}

\subsection{Nutrient uptake}

Prior to steady-state, the residual concentrations kinetics of $\mathrm{N}$ and $\mathrm{P}$ inside the bioreactors were drastically different when IC or IB modes were used (Fig. 3). Considering the IC mode, $\mathrm{N}$ and $\mathrm{P}$ residual concentrations slowly reduced until steady-state was reached. On the contrary, $\mathrm{N}$ and $\mathrm{P}$ residual concentrations in the IB modes dramatically reduced in the bioreactor until the continuous flow was started. Residual concentrations then increased up to steady-state concentrations.

At days 6-8, that is after steady-state was reached, $\mathrm{N}$ and $\mathrm{P}$ uptakes (Table 6) were not significantly different between IC and IB cultures (ANOVA test). In all the 10 cultures of both successive experiments steady-state mean uptake were $\rho_{\mathrm{N}}=83.3 \pm 2.0 \mathrm{fmol} \mathrm{N}$ cell $^{-1} \mathrm{~d}^{-1}$ and $\rho_{\mathrm{P}}=5.5 \pm 0.4 \mathrm{fmol} \mathrm{P}$ cell $^{-1} \mathrm{~d}^{-1}$.

\section{Discussion}

Results showed that IC mode had no significant impact on steady-state cellular density. Although the steady-state establishment period (between 6 and $8 \mathrm{~d}$ after inoculation in all the 10 cultures) was difficult to estimate, it seemed similar for IB and IC modes. The cumulated cell production of the two modes were similar too. Direct biomass determination showed no significant difference between IC and IB modes. This was confirmed by infrared absorbance.

The Chl $a$ cell content of culture grown using IC or IB mode proved to be very similar at steady-state. This result 

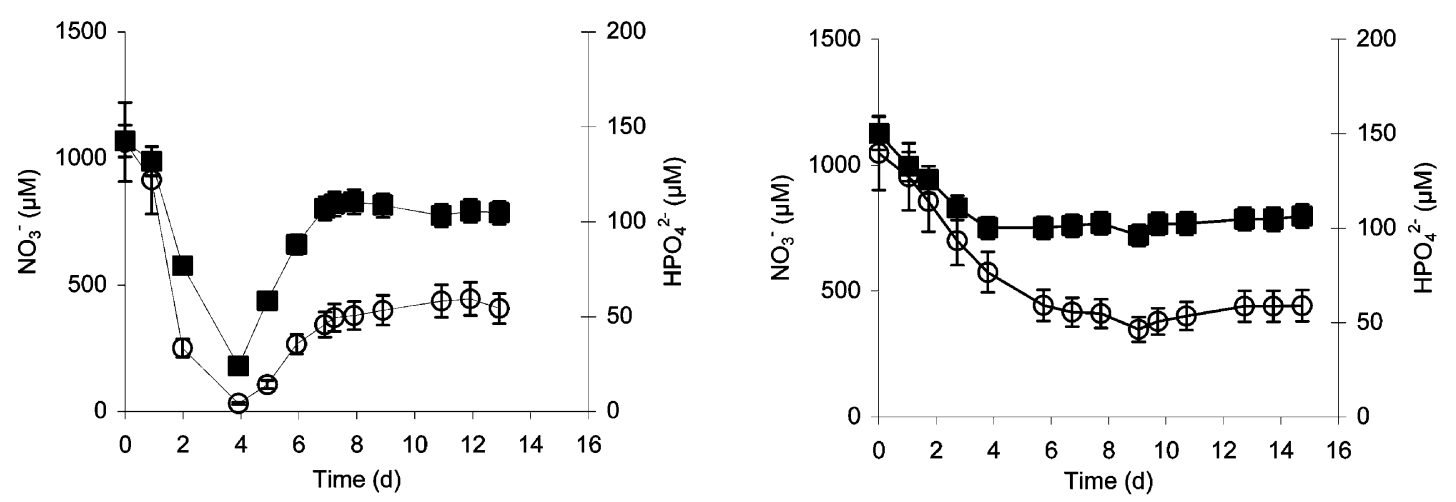

Fig. 3. Residual kinetics of $\mathrm{NO}_{3}{ }^{-}$(open circles) and $\mathrm{HPO}_{4}{ }^{2-}$ (filled squares) in an IB mode (left) and an IC mode (right) cultures during experiment 2. In the IB mode culture, continuous flowstarted at day 4 . Error bars represent the variation coefficient for $\mathrm{N}(\mathrm{CV}=14.6 \%)$; and $\mathrm{P}(\mathrm{CV}=5.8 \%)$.

Table 6

Mean $\mathrm{N}$ and $\mathrm{P}$ uptake per cell ( $\mathrm{fmol}$ cell $^{-1} \mathrm{~d}^{-1}$ ), measured at steady-state in the two experiments $(n=10)$. Ninety-five percent confidence intervals are given in brackets

\begin{tabular}{lllll}
\hline & Experiment 1 & \multicolumn{3}{c}{ Experiment 2} \\
& $\rho_{\mathrm{N}}$ & $\rho_{\mathrm{P}}$ & $\rho_{\mathrm{N}}$ & $\rho_{\mathrm{P}}$ \\
\hline IB & $79.6(5.1)$ & $5.8(0.7)$ & $82.3(3.5)$ & $5.0(0.4)$ \\
IC & $88.8(9.7)$ & $6.5(1.8)$ & $86.3(2.6)$ & $5.7(0.6)$ \\
\hline
\end{tabular}

agrees with the $\mathrm{Chl} a$ cell content of $0.2 \mathrm{pg}$ cell $^{-1}$ reported by Saoudi-Helis et al. (1994) in T-iso continuous flow culture at the same dilution rate. Chl $a$ degradation results in Pheo $a$ and is an indicator of the renewal rate of $\mathrm{Chl} a$ pool and phenomena of senescence and cellular mortality (Louda et al., 1998). Once steady-state was reached, the two initial modes IC and IB led to the same ratio of $\mathrm{Chl} a$ degradation, indicating that preliminary phase of the culture had no influence on Chl $a$ renewal rate and cell senescence. IC and IB modes induced same $P_{\mathrm{g}}{ }^{\max }$ and $R$ rates at steady-state, the latter was $30 \%$ of $P_{\mathrm{g}}{ }^{\max }$. Among prymnesiophyceae, Langdon (1993) estimates $R / P_{\mathrm{g}}{ }^{\max }$ ratio to $0.16( \pm 0.06)$. This was confirmed by Falkowski (1985) who observed a ratio of 0.17 on I. galbana. The $R / P_{\mathrm{g}}{ }^{\max }$ ratio presented here is then twofold higher. However, it has been shown that the respiration of microalgae in continuous cultures at steady-state could vary from $5 \%$ to $60 \%$ of gross photosynthesis and could be related to environmental conditions and physiological status of the microalgae (Collos, 1997).

Before steady-state was reached IC and IB modes induced very different residual nutrient kinetics in the bioreactors. On the other hand, $\mathrm{N}$ and $\mathrm{P}$ steady-state residual concentrations were very similar when using IC or IB mode. At steady-state, $83 \mathrm{fmol} \mathrm{N} \mathrm{cell}^{-1}$ and $5.5 \mathrm{fmol} \mathrm{P}^{\mathrm{P}}$ cell ${ }^{-1}$ cell quotas were found for T-iso for both IC and IB modes. It is about half the $170 \mathrm{fmol} \mathrm{N} \mathrm{cell}^{-1}$ uptake reported by Fidalgo et al. (1998) on I. galbana during exponential growth. But our results are similar to the $60 \mathrm{fmol} \mathrm{N}$ cell $^{-1}$ and $2.5 \mathrm{fmol} \mathrm{P}$ cell $^{-1}$ reported by Elrifi and Turpin (1985) on Selenastrum minutum using N or P limiting medium and to the $60 \mathrm{fmol} \mathrm{N} \mathrm{cell}{ }^{-1}$ and $1.8 \mathrm{fmol}$ $\mathrm{P}$ cell $^{-1}$ reported by Terry (1982) and Terry et al. (1985) on $P$. lutheri at the same dilution rate.
Under the prevailing experimental conditions, namely initial cell density and dilution rate, the cell population, the photosynthetic apparatus and the nutrient uptake of the IC grown cultures were found to be very similar to those of IB grown cultures. Results confirmed chemostat theory and showed that IC mode could be an alternative for experimental cultures as it could contribute to higher flexibility in planning and running chemostat cultures.

\section{References}

Alonso, D.L., Belarbi, E.-H., Fernandez-Sevilla, J.M., Rodriguez-Ruiz, J., Molina-Grima, E., 2000. Acyl lipid composition variation related to culture age and nitrogen concentration in continuous culture of the microalga Phaeodactylum tricornutum. Phytochemistry 54, 46-471.

Borowitzka, M.A., 1999. Commercial production of microalgae: ponds, tanks, tubes and fermenters. J. Biotechnol. 70, 313-321.

Brown, M.R., Garland, C.D., Jeffrey, S.W., Jameson, I.D., Leroi, J.M., 1993. The gross and amino acid compositions of batch and semi-continuous cultures of Isochrysis sp. (clone T.ISO), Pavlova lutheri and Nannochloropsis oculata. J. Appl. Phycol. 5, 285-296.

Brown, M.R., McCausland, M.A., Kowalski, K., 1998. The nutritional value of four Australian microalgal strains fed to Pacific oyster Crassostrea gigas spat. Aquaculture 165, 281-293.

Collos, Y., 1997. A physiological basis for estimating inorganic carbon release during photosynthesis by natural phytoplankton. Ecol. Model. 96, 285-292.

D'Souza, F.M.L., Kelly, G.J., 2000. Effects of a diet of a nitrogen-limited alga (Tetraselmis suecica) on growth, survival and biochemical composition of tiger prawn (Penaeus semisulcatus) larvae. Aquaculture 181, 311-329.

Elrifi, I.R., Turpin, D.H., 1985. Steady-state luxury consumption and the concept of optimum nutrient ratios: a study with phosphate and nitrate limited Selenastrum minutum (Chlorophyta). J. Phycol. 21, 592-602.

Fabregas, J., Herrero, C., Abalde, J., Cabezas, B., 1985. Growth, chlorophyll a and protein of the marine microalga Isochrysis galbana in batch cultures with different salinities and high nutrient concentrations. Aquaculture 50, 1-11.

Fabregas, J., Herrero, C., Cabezas, B., Abalde, J., 1986. Biomass production and biochemical composition in mass cultures of the marine microalga Isochrysis galbana Parke at varying nutrient concentrations. Aquaculture 53, 101-113.

Falkowski, P.G., 1985. Growth-irradiance relationships in phytoplankton. Limnol. Oceanogr. 30, 311-321. 
Fernandez, F.G.A., Camacho, F.G., Perez, J.A.S., Sevilla, J.M.F., Grima, E.M., 1998. Modeling of biomass productivity in tubular photobioreactors for microalgal cultures: effects of dilution rate, tube diameter, and solar irradiance. Biotechnol. Bioeng. 58, 605-616.

Fidalgo, J.P., Cid, A., Torres, E., Sukenik, A., Herrero, C., 1998. Effects of nitrogen source and growth phase on proximate biochemical composition, lipid classes and fatty acid profile of the marine microalga Isochrysis galbana. Aquaculture 166, 105-116.

Langdon, C., 1993. The significance of respiration in production measurements based on oxygen. Measurement of primary production from the molecular to the global scale. ICES Mar. Sci. Symp. 197, 69-78.

Lorenzen, C.J., 1967. Determination of chlorophyll and pheopigments: spectrophotometric equations. Limnol. Oceanogr. 12, 343-346.

Louda, J.W., Li, J., Liu, L., Winfree, M.N., Baker, E.W., 1998. Chlorophyll- $a$ degradation during cellular senescence and death. Org. Geochem. 29, 1233-1251.

McCausland, M.A., Brown, M.R., Barrett, S.M., Diemar, J.A., Heasman, M.P., 1999. Evaluation of live microalgae and microalgal pastes as supplementary food for juvenile Pacific oysters (Crassostrea gigas). Aquaculture 174, 323-342.

Molina Grima, E., Fernandez-Sevilla, J.M., Sanchez Perez, J.A., Garcia Camacho, F., 1996. A study on simultaneous photolimitation and photoinhibition in dense microalgal cultures taking into account incident and averaged irradiance. J. Biotechnol. 45, 59-69.

Otero, A., Fabregas, J., 1997. Changes in the nutrient composition of Tetraselmis suecica cultured semicontinuously with different nutrient concentrations and renewal rates. Aquaculture 159, 111-123.

Phatarpekar, P.V., Sreepada, R.A., Pednekar, C., Achuthankutty, C.T., 2000. A comparative study on growth performance and biochemical composition of mixed culture of Isochrysis galbana and Chaetoceraos calcitrans with monocultures. Aquaculture 181, 141-155.
Rebolloso Fuentes, M.M., Acien Fernandez, G.G., Sanchez Perez, J.A., Guil Guerrero, J.L., 2000. Biomass nutrient profiles of the microalga Porphyridium cruentum. Food Chem. 70, 345-353.

Robert, R., Trintignac, P., 1997. Substitutes for live microalgae in mariculture: a review. Aquat. Living Res. 10, 315-327.

Saoudi-Helis, L., Dubacq, J.P., Marty, Y., Samain, J.F., Gudin, C., 1994. Influence of growth rate on pigment and lipid composition of the microalga Isochrysis aff. galbana clone T.iso. J. Appl. Phycol. 6, 315322.

Schmitt, D., Müller, A., Csögör, Z., Frimmel, F.H., Posten, C., 2001. The adsorption kinetics of metal ions onto different microalgae and siliceous earth. Water Res. 35, 779-785.

Sciandra, A., Lazzara, L., Claustre, H., Babin, M., 2000. Response of growth rate, pigment composition and optical properties of Cryptomonas sp. to light and nitrogen stresses. Mar. Ecol-Prog. Ser. 201, 107-120.

Terry, K.L., 1982. Nitrate and phosphate uptake interactions in a marine Prymnesiophyte. J. Phycol. 18, 79-86.

Terry, K.L., Laws, E.A., Burns, D.J., 1985. Growth rate variation in the N:P requirement ratio of phytoplankton. J. Phycol. 21, 323-329.

Valenzuela-Espinoza, E., Millan-Nunez, R., Nunez-Cebrero, F., 1999. Biomass production and nutrient uptake by Isochrysis aff. galbana (Clone T-ISO) cultured with a low cost alternative to the $\mathrm{f} / 2$ medium. Aquac. Eng. 20, 135-147.

Versteegh, G.J.M., Riegman, R., de Leeuw, J.W., Jansen, J.H.F., 2001. U37K' values for Isochrysis galbana as a function of culture temperature, light intensity and nutrient concentrations. Org. Geochem. 32, 785-794.

Walne, P.R., 1966. Large-scale culture of larvae of Ostrea edulis. L. Fish. Invest. (Lond) Ser. II, 25, 1-53.

Zhu, C.J., 1997. Effects of temperature and growth phase on lipid and biochemical composition of Isochrysis galbana TK1. J. Appl. Phycol. 9, $451-457$. 